\title{
PENGARUH PEMBERIAN RANGE OF MOTION (ROM) PASIF TERHADAP FLEKSIBILITAS SENDI PADA LANSIA DI PANTI SOSIAL TRESNA WERDA MINAULA KENDARI
}

\author{
Sahmad $^{1}$, Reni Yunus ${ }^{1}$, Andi Sarmawan ${ }^{2}$ \\ ${ }^{1}$ Poltekkes Kemenkes Kendari \\ ${ }^{2}$ STIKES Karya Kesehatan Kendari
}

\begin{abstract}
Aging is a physiological process that will reduce all the functions of organs, one of which is on the musculoskeletal system which can lead to limited motion. This study aimed to determine the effect of Range Of Motion (ROM) of the passive joint flexibility in the elderly in PSTW Minaula Kendari. This research was conducted in PSTW Minaula Kendari. Number of samples 12 people. This study uses the design of one group pretest-posttest. Leverage data is done through observation and documentation. Data were analyzed using paired t-test at $95 \%$ confidence level with a $=0.05$ using computerized tools (SPSS-20). The results showed that there is the effect of passive ROM tehadap right knee joint flexibility by providing flexion $(p=0.00)$, extension $(p=0.00)$, the left knee with the provision of flexion $(p=0.01)$, extension $(p=0.00)$, with the provision of the right ankle dorsi flexion $(\mathrm{p}=0.00)$, plantar flexion $(\mathrm{p}=0.00)$, the left ankle with the provision of dorsi flexion $(\mathrm{p}=0.00)$, plantar flexion $(p=0.00)$, the right foot by giving inverse $(p=0.00)$, eversion $(p=0.00)$, the left foot by giving inverse $(p=0.00)$, eversion $(p=0.00)$. The conclusion of this study is to show that there is the effect of passive ROM to the flexibility of the joints in the elderly.
\end{abstract}

\section{Keyword: ROM exercises, fleksibiliats joints, elderly}

\section{PENDAHULUAN}

Lanjut usia adalah bagian dari proses tumbuh kembang. Manusia tidak secara tibatiba menjadi tua, tetapi berkembang dari bayi, anak-anak, dewasa, dan akhirnya menjadi tua. Hal ini normal, dengan perubahan fisik dan tingkah laku yang dapat diramalkan yang terjadi pada semua orang pada saat mereka mencapai usia tahap perkembangan kronologis tertentu. Di masa ini seseorang mengalami kemunduran fisik, mental dan sosial secara bertahap (Azizah, 2011).

Data World Health Organisasion (WHO), pada abad 21 jumlah penduduk dunia yang berusia lanjut semakin melonjak. Di wilayah Asia Pasifik, jumlah berusia lanjut akan bertambah pesat mencapai 410 juta atau meningkat $16 \%$ tahun 2010 , dan menjadi 1,3 miliar atau 20\% lebih tinggi pada tahun 2025 (Muwarni , 2010).

Jumlah lansia di Indonesia pada tahun 2000 sebesar 7,28\% dan pada tahun 2020diperkirakan menjadi sekitar 11,34\%. Hasil Sensus Penduduk tahun 2010 menyatakanbahwa Indonesia termasuk ke dalam lima besar negara dengan jumlah penduduklansia terbanyak di dunia, yakni 18,1 juta jiwa atau 9,6\% dari jumlah penduduk. Data
BPS tahun 2012 terjadi peningkatan jumlah lansia menjadi $11,2 \%$. Peningkatan proporsi jumlah lansia tersebut perlu mendapatkan perhatian karena kelompok lansiamerupakan kelompok beresiko tinggi yang mengalami berbagai masalah kesehatan khususnya penyakit degeratif (Depkes RI, 2012).

Laporan Jumlah lanjut usia di Sulawesi tenggara pada tahun 2013 yang berusia 59 tahun sebesar 217.188 jiwa dan lanjut usia yang berusia 60 tahun sebesar 69.497 jiwa (Dinas Kesehatan Sulawesi tenggara). Data jumlah lanjut usia di kota Kendari adalah sebesar 5.703 jiwa (BPJS Kota Kendari, 2015).

Fleksibilitas atau kelenturan sendi merupakan suatu gerak maksimal yang dapat dilakukan oleh persendian yang meliputi hubungan antara bentuk persendian, otot, tendon dan ligamen sekeliling persendian (Nieman, 2011).

Proses menua menyebabkan penurunan produksi cairan sinovial pada persendian dan tonus otot, kartilago sendi menjadi lebih tipis dan ligamentum menjadilebih kaku serta terjadi penurunan kelenturan (fleksibilitas), sehingga mengurangi gerakan persendian. Kekakuan dapat disebabkan oleh adanya kalsifikasi pada 
lansia yang akan menurunkan fleksibilitas sendi.

Salah satu alat untuk mencatat batas pergerakan sendi adalah dengan menggunakan geniometer, yaitu suatu alat yang memakai sebuah busur derajat. Batas pergerakan sendi pada satu ekstremitas seharusnya sama dengan batas pergerakan yang terdapat pada sendi yang sama pada ektremitas yang berlawanan, yaitu dengan melakukan perbandingan yang teliti antara sendi yang terkena dengan pasangannya yang normal, perbedaan kecil yang terdapat dapat dinilai (Delp, 2006).

\section{METODE}

\section{Jenis Penelitian}

Jenis penelitian yang digunakan adalah pre eksperimen dengan pendekatan one group pretest posttest design yang rancangannya tidak ada kelompok pembanding (control), tetapi paling tidak sudah dilakukan observasi pertama (pretest) yang memungkinkan menguji perubahan-perubahan yang terjadi setelah adanya eksperimen (program) Notoatmodjo (2012).

\section{Lokasi dan Waktu Penelitian}

Penelitian ini dilaksanakan di PSTW Minaula Kendari, mulai tanggal 24 Mei - 24 Juni 2016.

\section{Populasi dan Sampel}

Populasi adalah semua lansia yang berada di Panti Sosial Tresna Wherda Minaula Kendari sebanyak 95 orang. Sampel adalah seluruh lansia yang mengalami gangguan fleksibilitas sendi. Sampel berjumlah 12 orang, pengambilan sampel dilakukan dengan cara total sampling.

\section{Teknik Pengumpulan Data}

Teknik pengumpulan data dalam penelitian ini adalah dengan cara melakukan pretest, posttest, observasi dan wawancara. Responden dilakukan pretest terlebih dahulu dengan cara mengukur kemampuan fleksibilitas sendi dengan menggunakan alat trigonometri atau busur derajat.

Setelah itu semua responden sebagai kelompok yang akan diberikan perlakuan dilakukan intervensi dengan cara pemberian Range Of Motion (ROM) pada sendi lutut, kaki, dan mata kaki yang mengalami kekakuan sendi dengan cara latihan gerak sendi dengan gerakan fleksi, ekstensi, dorsofleksi, plantarfleksi, inversi dan eversi. Pemberian intervensi ini dilakukan 2 kali sehari yaitu pagi dan sore, pemberian intervensi dilakukan selama $10-20$ menit selama satu bulan. Setelah itu dilakukan post test untuk mengukur perkembangan responden dalam melakukan fleksibilitas sendi dengan menggunakan alat ukur trigonometri.

\section{Analisa data}

Uji yang digunakan dalam penelitian ini adalah paired t-test dan tingkat kebermaknaan data yang dipilih adalah $\mathrm{p} \leq 0,05$.

\section{HASIL PENELITIAN}

Karakteristik subyek penelitian

Pada penelitian ini frekuensi umur responden yang berada antara 60 - 70 tahun ada 3 orang (25\%), antara $71-80$ tahun ada 5 orang $(41,67 \%)$, antara $81-90$ tahun ada 2 orang $(16,67 \%)$, dan berusia diatas 90 tahun ada 2 orang $(16,67 \%)$. Responden berjenis kelamin laki-laki lebih banyak yaitu berjumlah 7 orang $(58,33 \%)$, dan responden berjenis kelamin perempuan berjumlah 5 orang $(41,67 \%)$. Responden berpendidikan SMA sebanyak 1 orang $(8,33 \%)$, SD sebanyak 8 orang $(66,67 \%)$ dan TS sebanyak 3 orang (25\%\%).

\section{Gambaran Skor Fleksibilitas Sendi Lutut Responden Sebelum dan Setelah diberikan Intervensi di PSTW Minaula Kendari}

Berdasarkan hasil penelitian diketahui bahwa rata-rata fleksibilitas sendi lutut sebelum dan setelah diberikan ROM pasif fleksi sendi lutut kanan sebelum diberikan perlakuan dengan nilai mean 104,17, standar deviasi 5,149 sedangkan hasil setelah diberikan perlakuan nilai mean 106,92, standar deviasi 5,485 sementara untuk nilai $p$ value 0,00 . Pada fleksi sendi lutut kiri sebelum diberikan perlakuan dengan nilai mean 105,58 standar deviasi 5,265 dan nilai sedangkan untuk hasil setelah diberikan perlakuan nilai mean 109,08 dan standar deviasi 4,699, sementara untuk nilai $p$ value 0,01 .

Pada pemberian ekstensi sendi lutut kanan sebelum diberikan perlakuan dengan nilai mean 103,92, standar deviasi 4,833 sedangkan hasil setelah diberikan perlakuan nilai mean 107,00 , standar deviasi 4,843 dengan nilai $p$ value 0,00 . Pada pemberian ekstensi sendi lutut kiri sebelum diberikan perlakuan dengan nilai mean 105,00 standar deviasi 4,690 sedangkan untuk hasil setelah diberikan perlakuan nilai mean 108,58 dan 
standar deviasi 4,400 Sementara untuk nilai $p \quad$ value 0,00.

Tabel 1. Distribusi Karakteristik Responden berdasarkan Umur, Jenis Kelamin, dan Pendidikan

\begin{tabular}{lcc}
\hline Karakteristik Responden & $\mathbf{n = 1 2}$ & Persen (\%) \\
\hline Umur Reponden (tahun) & 3 & \\
$60-70$ & 5 & 25 \\
$71-80$ & 2 & 41,67 \\
$81-90$ & 2 & 16,67 \\
$>90$ & & 16,67 \\
\hline Jenis Kelamin Responden & 7 & \\
Laki-laki & 5 & 58,33 \\
Perempuan & & 41,67 \\
\hline Pendidikan Responden & 3 & 25 \\
Tidak Sekolah & 8 & 66,67 \\
SD & 1 & 8,33 \\
SMA & &
\end{tabular}

Gambaran Skor Fleksibilitas Sendi Mata Kaki Responden Sebelum dan Setelah diberikan Intervensi Di PSTW Minaula Kendari

Rata-rata fleksibilitas sendi mata kaki sebelum dan setelah diberikan ROM pasif dorsi fleksi sendi mata kaki kanan sebelum diberikan perlakuan dengan nilai mean 9,75 , standar deviasi 3,388 sedangkan hasil setelah diberikan perlakuan nilai mean 12,33, standar deviasi 3,200 sementara untuk nilai $p$ value 0,00 . Pada Pemberian dorsi fleksi sendi mata kaki kiri sebelum diberikan perlakuan dengan nilai mean 10,08 standar deviasi 3,118 sedangkan untuk hasil setelah diberikan perlakuan nilai mean
12,58 dan standar deviasi 3,288 sementara untuk nilai dan nilai $p$ value 0,00 .

Pemberian plantar fleksi sendi mata kaki kanan sebelum diberikan perlakuan dengan nilai mean 31,08, standar deviasi 3,288 sedangkan hasil setelah diberikan perlakuan nilai mean 33,83, standar deviasi 3,326 sementara untuk nilai $p$ value 0,00 . Pada plantar fleksi sendi mata kaki kiri sebelum diberikan perlakuan dengan nilai mean 30,83 standar deviasi 3,243 sedangkan untuk hasil setelah diberikan perlakuan nilai mean 33,67 dan standar deviasi 3,055 Sementara untuk nilai dan nilai $p$ value 0,00 .

Tabel 2. Distribusi Rata-Rata Responden berdasarkan Fleksibilitas Sendi Lutut Sebelum dan Setelah diberikan Intervensi di PSTW Minaula Kendari Tahun 2016

\begin{tabular}{|c|c|c|c|c|c|c|}
\hline \multicolumn{7}{|c|}{ Variabel Penelitian Fleksibilitas Sendi Lutut } \\
\hline \multirow{2}{*}{ Rentang Gerak } & \multicolumn{2}{|c|}{ Mean } & \multirow{2}{*}{$\mathbf{N}$} & \multicolumn{2}{|c|}{ SD } & \multirow{2}{*}{ p-Value } \\
\hline & Pre & Post & & Pre & Post & \\
\hline Fleksi lutut kanan & 104,17 & 106,92 & 12 & 5,149 & 5,485 & 0,000 \\
\hline Fleksi lutut kiri & 105,58 & 109,08 & 12 & 5,265 & 4,699 & 0,001 \\
\hline Ekstensi lutut kanan & 103,92 & 107,00 & 12 & 4,833 & 4,843 & 0,000 \\
\hline Ekstensi lutut kiri & 105,00 & 108,58 & 12 & 4,690 & 4,400 & 0,000 \\
\hline
\end{tabular}

Gambaran Skor Fleksibilitas Sendi Kaki Responden Sebelum dan Setelah diberikan Intervensi di PSTW Minaula Kendari

Rata-rata fleksibilitas sendi kaki sebelum dan setelah diberikan ROM pasif inversi sendi kaki kanan sebelum diberikan perlakuan dengan nilai mean 3,67, standar deviasi 1,371 sedangkan hasil setelah diberikan perlakuan nilai mean 5,33 standar deviasi 1,231 sementara untuk nilai $p$ value 0,00. Pada inversi sendi kaki kiri sebelum diberikan perlakuan dengan nilai mean 3,50 standar deviasi 1,382 sedangkan untuk hasil setelah diberikan perlakuan nilai mean 5,50 dan 
standar deviasi 1,314 sementara untuk nilai $p$ value 0,00 . Pemberian dengan eversi sendi kaki kanan sebelum diberikan perlakuan dengan nilai mean 3,42 standar deviasi 0,996 sedangkan hasil setelah diberikan perlakuan nilai mean 5,42 standar deviasi 1,084 sementara untuk nilai $p$ value 0,00 . Pada eversi sendi kaki kiri sebelum diberikan perlakuan dengan nilai mean 3,50 standar deviasi 1,382 sedangkan untuk hasil setelah diberikan perlakuan nilai mean 5,83 dan standar deviasi 1,267 sementara untuk nilai $p$ value 0,00 .

Tabel 3. Distribusi Rata-Rata Responden berdasarkan Fleksibilitas Sendi Mata Kaki Sebelum dan Setelah diberikan Intervensi di PSTW Minaula Kendari Tahun 2016

\begin{tabular}{|c|c|c|c|c|c|c|}
\hline \multicolumn{7}{|c|}{ Variabel Penelitian Fleksibilitas Sendi Mata Kaki } \\
\hline \multirow{2}{*}{ Rentang Gerak } & \multicolumn{2}{|c|}{ Mean } & \multirow{2}{*}{$\mathbf{N}$} & \multicolumn{2}{|c|}{ SD } & \multirow{2}{*}{ p-Value } \\
\hline & Pre & Post & & Pre & Post & \\
\hline Dorsi fleksi mata kaki kanan & 9,75 & 12,33 & 12 & 3,388 & 3,200 & 0,000 \\
\hline Dorsi fleksi mata kaki kiri & 10,08 & 12,58 & 12 & 3,118 & 3,288 & 0,000 \\
\hline Plantar fleksi mata kaki kanan & 31,08 & 33,83 & 12 & 3,288 & 3,326 & 0,000 \\
\hline Plantar fleksi mata kaki kiri & 30,83 & 33,67 & 12 & 3,243 & 3,055 & 0,000 \\
\hline
\end{tabular}

Tabel 4. Distribusi Rata-Rata Responden berdasarkan Fleksibilitas Sendi Kaki Sebelum dan Setelah diberikan Intervensi di PSTW Minaula Kendari Tahun 2016

\begin{tabular}{|c|c|c|c|c|c|c|}
\hline \multicolumn{7}{|c|}{ Variabel Penelitian Fleksibilitas Sendi Kaki } \\
\hline \multirow{2}{*}{ Rentang Gerak } & \multicolumn{2}{|c|}{ Mean } & \multirow{2}{*}{$\mathbf{N}$} & \multicolumn{2}{|c|}{ SD } & \multirow{2}{*}{ p-Value } \\
\hline & Pre & Post & & Pre & Post & \\
\hline Inversi kaki kanan & 3,67 & 5,33 & 12 & 1,371 & 1,231 & 0,000 \\
\hline Inversi kaki kiri & 3,50 & 5,50 & 12 & 1,382 & 1,314 & 0,000 \\
\hline Eversi kaki kanan & 3,42 & 3,52 & 12 & 0,996 & 1,084 & 0,000 \\
\hline Eversi kaki kiri & 3,50 & 5,83 & 12 & 1,382 & 1,267 & 0,000 \\
\hline
\end{tabular}

\section{PEMBAHASAN}

Berdasarkan hasil analisis t-test, diperoleh nilai $p<\alpha 0,05$. Dari hasil tersebut maka terdapat perbedaan antara pretest dan posttest rentang gerak pada kelompok perlakuan setelah dilakukan latihan Range of Motion (ROM) pasif. Rata-rata rentang gerak sendi lutut, mata kaki, dan kaki pada lansia di Panti sosial tresna werda minaula kendari sebagai kelompok perlakuan meningkat. Dari hasil tersebut, maka dapat disimpulkan bahwa ada pengaruh latihan Range Of Motion (ROM) pasif terhadap peningkatan rentang gerak sendi pada lansia.

Hasil peneltian ini sesuai dengan penelitian Soempeno, dkk (2007) tentang "Pengaruh Latihan Range Of Motion (ROM) pasif Terhadap Fleksibilitas Sendi Lutut pada Lansia di Panti Wreda Wening Wardoyo Ungaran". Penelitian ini menunjukkan bahwa ada peningkatan yang signifikan antara pengukuran pertama-kedua pada fleksi lutut kanan dan kiri dan antara pengukuran pertamaketiga pada fleksi sendi lutut kiri. Adanya pergerakan pada persendian akan menyebabkan terjadinya peningkatan aliran darah kedalam kapsula sendi dan memberikan nutrisi yang memungkinkan tulang untuk bergerak dengan lancar dan tanpa rasa sakit atau ketidaknyamanan (Jenkins, 2005).

Latihan ROM pasif terbukti tidak hanya meningkatkan rentang gerak tetapi juga dapat mempertahankan rentang gerak. Hal ini terlihat dari hasil penelitian yang menunujukkan bahwa padapre test danpost test terlihat rata-rata rentang gerak sendi lutut, mata kaki, dan kaki lansia mengalami peningkatan.

Jika terjadi penurunan gerak atau mobilitas maka aliran darah berkurang, sendi menjadi kaku dan menyakitkan, hal ini menyebabkan penurunan aktivitas dan pada akhirnya rentang gerak akan semakin mengalami penurunan dan keterbatasan gerak (Jenkins, 2005). Latihan Range of Motion (ROM) pasif adalah latihan ROM yang dilakukan oleh pasien dengan bantuan perawat dari setiap gerakan yang dilakukan. Indikasi latihan pasif adalah semua pasien yang dirawat 
yang tidak mampu melakukan ROM sendiri dan kooperatif. Manfaat dari latihan ROM pasif memperbaiki tonus otot, meningkatkan mobilisasi sendi, memperbaiki toleransi otot untuk latihan, meningkatkan massa otot dan mengurangi kehilangan tulang. Untuk latihan ROM aktif, klien dianjurkan untuk melakukan gerakan sesuai yang sudah diajarkan, hindari perasaan ketidaknyamanan saat latihan dilakukan, gerakan dilakukan secara sistematis dengan urutan yang sama dalam setiap sesi, setiap gerakan dilakukan tiga kali denga frekuensi dua kali sehari.

Dosis dan intensitas latihan ROM yang dianjurkan menunjukkan hasil cukup bervariasi. Secara teori tidak disebutkan secara spesifik mengenai dosis dan intensitas latihan ROM tersebut, namun dari berbagai literature dan hasil penelitian tentang manfaat latihan ROM dapat dijadikan sebagai rujukan dalam menerapkan latihan ROM sebagai salah satu intervensi.

Penelitian Utami (2009) dengan latihan ROM rutin sedikitnya $2-3$ kali setiap minggunya dalam waktu $20-30$ menit memberikan manfaat yang berarti diantaranya dapat meningkatkan kekuatan otot dan menurunkan keletihan, dalam hal ini dikhususkan pada lansia yang mengalami penurunan massa otot serta kekuatannya untuk melakukan mobilisasinya. Hasil dari penelitian ini didapatkan bahwa kemampuan mobilisasi pada lansia setelah dilakukan latihan Rom pasif lebih baik dari sebelum dilakukan latihan Rom pasif. Smeltzer dkk (2008) menyebutkan bahwa latihan ROM dapat dilakukan 4 sampai 5 kali sehari, dengan waktu 10 menit untuk setiap latihan.

Kekakuan dapat menyebabkan menurunnya lingkup gerak sendi lutut, mata kaki, dan kaki dan menambah nyeri sendi karena berfungsi sebagai penopang tubuh maka mempunyai struktur ligamentum yang lebih kuat dan banyak dari pada sendi lainnya walaupun keduanya sama-sama. Hal ini juga akan mempengaruhi kemungkinan terjadinya kekakuan yang lebih besar pada sendi lutut, kaki, dan mata kaki tersebut.

Adanya keterbatasan pergerakan dan berkurangnya pemakaian sendi dapat memperparah kondisi tersebut. Penurunan kemampuan muskuloskeletal dapat menurunkan aktivitas fisik (physical activity) dan latihan (exercise), sehingga akan mempengaruhi lansia dalam melakukan aktivitas kehidupan sehari- hari (Activity Daily Living atau ADL) sehingga Quality of life menurun.

Fleksibilitas sendi lutut dapat diartikan sebagai kemampuan jaringan di sekitar persendian lutut untuk menghasilkan peregangan tanpa adanya gangguan dan kemudian relaks. Bagi orang berusia lanjut, di mana terjadi penurunan fleksibilitas sendi dari usia 30 - 70 tahun bisa mencapai $40-50 \%$ dianjurkan melakukan aktivitas bergerak bebas pada persendian untuk mencegah proses degenerasi dengan gerakan yang tidak menimbulkan beban berlebihan pada otot, sehingga ada kesempatan otot untuk melakukan pemulihan pada tahap awal, latihan diutamakan pada kelenturan sendi dengan peregangan dan secara bertahap ditingkatkan dengan latihan kekuatan, namun harus dilakukan secara hatihati dan perlahan.

Penelitian Ulliya (2007), merupakan eksperimen dengan pre post test design. Subyek sebanyak 8 yang dilakukan latihan ROM sebanyak 5 kali dalam seminggu selama 6 minggu. Fleksibilitas sendi diukur pada sebelum, setelah 3 minggu dan setelah 6 latihan ROM. Hasil penelitian menunjukkan bahwa ada peningkatan yang signifikan antara pengukuran pertama-kedua pada fleksi sendi lutut kanan dan kiri dan antara pengukuran pertama-ketiga pada fleksi sendi lutut kiri. Simpulan pada penelitian ini adalah latihan ROM selama dapat meningkatkan fleksibilitas sendi lutut kiri sebesar $35^{\circ}$ atau 43,75\%. Hasil-hasil penelitian ini menunjukkan bahwa pemberian ROM pasif memberikan pengaruh atau efek yang positif terhadap fleksibilitas sendi.

\section{KESIMPULAN}

Berdasarkan hasil penelitian dapat disimpulkan bahwa ada pengaruh pemberian Range Of Motion (ROM) Pasif terhadap Fleksibilitas Sendi lutut, sendi mata kaki, sendi kaki pada Lansia di PSTW Minaula Kendari. Hal ini dibuktikan dengan hasil uji statistik ttest secara komputerisasi, maka diperoleh hasil $p$ value $=0,000<\alpha=0,05$ yang berarti terdapat pengaruh yang signifikan antara pemberian Range Of Motion (ROM) terhadap peningkatan fleksibilitas sendi pada lansia dan menunjukan $\mathrm{H}_{\mathrm{o}}$ ditolak dan $\mathrm{H}_{\mathrm{a}}$ diterima.

Berdasarkan hasil penelitian maka saran yang dapat penulis sampaikan bagi petugas kesehatan di Panti Sosial Tresna Werda Minaula Kendari untuk menanggulangi kejadian penurunan fleksibilitas sendi 
khususnya pada lansia dan lebih meningkatkan kegiatan penyuluhan untuk memberikan informasi tentang pentingnya latihan gerak salah satunya Range Of Motion (ROM) serta memberikan dorongan dan motivasi bagi masyarakat yang menderita penurunan fleksibilitas sendi. Penelitian ini diharapkan dapat menjadi bahan pustaka atau info tambahan bagi peneliti-peneliti selanjutnya yang ingin mengembangkan penelitian ini.

\section{DAFTAR PUSTAKA}

Arikunto S. (2010). Prosedur Penelitian Suatu Pendekatan Praktik. Jakarta: Rineka Cipta.

Astrand PO, Rodahl K, Dahl HA, Stromme SB. (2003). Textbook of Work Physiologi ed 4th. New York. McGraw-Hill.

Azizah M. L. (2011). Keperawatan Lanjut Usia. Jakarta : Graha Ilmu.

Badrusshalih. (2008). Batas-Batas Usia Lanjut. http://ahmadfikri.blogspot.com. Diakses 15 februari 2016.

Bandiyah. (2009). Lanjut Usia Dan Keperawatan Gerontik. Yogyakarta: Nuha Medika.

Darmojo, dan Martono. (2006). Buku Ajar Geriatri (Ilmu Kesehatan Usia Lanjut). Jakarta: Balai Penerbit FK UI.

Delp, dan Manning. (2006). Major Diagnosis Fisik. Jakarta: EGC.

Depkes RI. (2012). Jumlah Lansia Di Indonesia.http://eprints.ung.ac.id/12327/2 /2015. Diakses 15 Februari 2016.

Dinkes Sulawesi Tenggara, Profil Kesehatan Kesehatan Sultra. Kendari. 2015.

Indhah siswoyowati. (2013). Pengaruh pemberian Range Of Motion ( ROM) Aktif Terhadap Fleksibilitas Sendi Lutut pada Lansia di Desa Leyangan Kecamatan Ungaran Kabupaten Semarang. Skripsi STIKES Ngudi Waluyo Ungaran.

Jenkins. (2005). Pharmacokinetics. CRC Press LLC.

Kementerian Sosial RI Direktorat Pelayanan
Sosial Lanjut Usia, 2011: 4.

Lilik. (2011). Keperawatan Lanjut Usia. Yogyakarta: Graha Ilmu.

Lukman dan Ningsih. (2012). Asuhan Keperawatan Pada Klien dengan. Gangguan Sistem Muskuloskeletal. Jilid 1. Jakarta: Salemba Medika.

Media Pembelajaran, Klasifikasi Sendi Berdasarkan Adanya Gerak http://digilib.itb.ac.id/files/disk1/553/jbpt itbpp-gdl-lindaandri-27616. Diakses 15 Februari 2016.

Murwani A, dan Priyantari W. (2011). Gerontik Konsep Dasar dan Asuhan Keperawatan Home Care dan Komunitas. Fitramaya, Yogyakarta.

Nieman. (2011). Exercise Testing and Prescription: A Health-Related Approach. Seventh Edition. New York: McGraw-Hill.

Nugroho W. (2009). Komunikasi dalam Keperawatan Gerontik. Jakarta: EGC.

Notoatmodjo. (2012). Metodologi penelitian kesehatan-Ed. Rev.-jakarta: Rineka cipta.

Panti Sosial Tresna Werdha Minaula Kendari. Pusat Data dan Informasi PSTW Minaula Kendari 2016.

Pudjiastuti S., dan Utomo B. (2003). Fisioterapi pada Lansia. Jakarta: EGC.

Potter, Patricia A. \& Perry, Anne Griffin. (2006). Buku Ajar Fundamental Keperawatan, Edisi 4. Jakarta: EGC.

Setiadi, Riswanda. (2010). Analisis dan Interpretasi Data Melalui Pendekatan Kuantitatif dan Kualitatif. UPI: Tidak diterbitkan.

Sugiyono. (2011). Metode Penelitian Kuantitatif, Kualitatif, dan R\&D. Bandung: Afabeta, Cv.

Tamher S. (2012). Kesehatan Usia Lanjut dengan Pendekatan Asuhan Keperawatan. Jakarta: Salemba Medika.

UUD No. 12 tahun 1996 (Direktorat Jenderal Departemen Hukum dan HAM).

UUD Republik Indonesia Nomor 4 tahun 1965, tentang Bantuan Penghidupan Jompo. 